Asian Review of Social Sciences

ISSN: 2249-6319 Vol.8 No.2, 2019, pp. 1-3

(C) The Research Publication, www.trp.org.in

\title{
Understanding Gift: From Mauss to Derrida
}

\author{
Sudeepta Ghose \\ Assistant Professor in Political Science, Serampore College, Serampore, West Bengal, India \\ E-Mail: sudeeptaghose@ rediffmail.com
}

\begin{abstract}
This paper probes into the practice of gift-giving and tries to find out the true character of gift. The paper begins with the common perception about gifts and proceeds to present an insightful analysis of Marcel Mauss' understanding of gift. It then delves into Jacques Derrida's take on the subject. The paper brings out the moments of convergences and divergences in thoughts of Mauss and Derrida before drawing up some conclusions about the nature of gift and its differences with other forms of exchange.
\end{abstract}

Keywords: Gift, Obligations, Exchange, Honour, Return Gift

\section{INTRODUCTION}

In common perception gift-giving does not involve any kind of exchange between the gift-giver and the gift-recipient. Gifts are supposed to be bestowed out of affection or compassion or courtesy without any expectation of being reciprocated and, in words of Emerson, "it is always so pleasant to be generous, though very vexatious to pay debts" (Emerson, 1898, p. 153). This perception trivialises the act of gift-giving as an uncomplicated performance sans any underlying consideration. True, unlike different forms of exchange, reciprocation is not that conspicuous here. Nevertheless, gifts do nurture both overt and subtle binding relations and obligations.

\section{UNDERSTANDING MAUSS}

Marcel Mauss in his seminal work, The Gift: Forms and Functions of Exchange in Archaic Societies, elaborates on obligations that the custom of gift-giving fostered in ancient societies especially in those of Polynesia, Melanesia, and North West America. For him, because of the recognition of certain obligations gifts were not, in reality, 'no strings attached' gifts and the practice of gift-giving, in these societies, involved notions of exchange. In fact, for Mauss, gift-giving in these societies was a type and function of exchange having its own set of rules and binding the participants by different obligations - as contracts do in other kinds of exchange. In Polynesia, he observes, not only were objects of economic value exchanged in forms of gifts between groups but also "courtesies, entertainments, ritual, military assistance, women, children, dances and feasts" (Mauss, 2011, p. 3), which led to more long lasting ties. For Mauss, "presentations which are in theory voluntary, disinterested and spontaneous, but are in fact obligatory and interested. The form usually taken is that of the gift generously offered; but the accompanying behaviour is formal pretence and social deception, while the transaction itself is based on obligation and economic self-interest." (Mauss, 2011, p.1)
Mauss identifies the prevalence of three obligations that shaped the practice of gift-exchange in the societies he studied. Apart from the easily recognisable obligation to reciprocate, which presupposes all forms of exchange, Mauss identifies two more obligations. First, for Mauss, there was the obligation to give - it was essential to give gifts on certain occasions and failing to do so would put one's honour at stake. For example, the chief of a society was bound to bestow in certain occasions to retain her/his honour. Failure to bestow led to the loss of honour and put one's preeminent position at stake. Next, there was the obligation to receive, that is, it was binding to receive a gift under certain circumstances. Though we usually assume that the intended gift-recipient has the autonomy to decide whether to accept a gift or not Mauss showcases that it was binding to accept gifts in the societies he studied. The obligation to receive was as compelling as the obligation to give for refusing to accept a gift exposed one's "fear of having to repay, and of being abased in default" (Mauss, 2011 , p. 39) and consequently led to the loss of honour. Nevertheless, Mauss points out that there were exceptional situations where refusals could be "assertion of victory and invincibility" (Mauss, 2011, p. 39). Finally, there was the obligation to reciprocate, that is, on having received a gift one was expected to offer a return gift. In fact, Mauss remarks, "The obligation of worthy return is imperative" (Mauss, 2011, p. 41). Failing to return a suitable gift put one's honour at stake and established the superiority of the original gift-giver. In case one failed to meet the third obligation, the original gift-giver got an opportunity "to show that one is something more and higher, that one is magister. To accept without returning or repaying more is to face subordination, to become a client and subservient, to become minister.'(Mauss, 2011, p. 72) Though not specifically identified as an obligation by Mauss one can assume that the failure to fulfil the third obligation led to another obligation - the obligation of indebtedness - and the subsequent loss of honour. What comes out of Mauss' understanding is that none of these three obligations could be bypassed nor the order changed and it was the notion of honour that was inextricably linked to these obligations.

The recognition and preponderance of these obligations ensured the continuous exchange of gifts. This, in turn, created bonds of solidarity between individuals and groups involved in the exchange process. Failing to honour these obligations led to the loss of honour, ruptured the bonds of solidarity and at times culminated in violence. Thus, one can easily conclude that honouring of these obligations were 
crucial. What one also gets to know from Mauss' study is that there were occasional instances of return gifts being of greater value than original gifts. Such acts of munificence were often intended to belittle the original gift-giver under circumstances where the giver-recipient relationship did not have a mutually accepted hierarchy of status and there was competition to gain higher status between the two parties. Thus, one can argue, gift-exchange has the inherent quality of emerging as an endless process till one fails in fulfilling any one of the three obligations identified by Mauss. Till the time one party fails in honouring any of these three obligations an incessant struggle can ensue with both parties trying to outdo the other by continuously giving and returning gifts of higher values. Nevertheless, gift-exchange also rejuvenates the bonds of association between the competing parties as they become involved in a continuous relation of exchange.

\section{UNDERSTANDING DERRIDA}

In Given Time I: Counterfeit Money Jacques Derrida takes up Mauss' argument that gifts are forms and functions of exchange. He accepts this as the premise of his arguments as well. Yet, from here begins Derrida's point of departure. He departs to the extent of categorically stating that gifts do not exist ---"The truth of the gift is equivalent to the nongift or to the non-truth of the gift" (Derrida, 1994, p. 27). In his journey of departure Derrida meticulously highlights the inconsistencies in Mauss' work. He argues, "On the one hand, Mauss reminds us that there is no gift without bond, without bind, without obligation or ligature; but on the other hand, there is no gift that does not have to untie itself from obligation, from debt, contract, exchange, and thus from the bind." (Derrida, 1994, p. 27) Criticising Mauss' work, which is one of the most acclaimed researches on gift, Derrida observes that it "speaks of everything but the gift .... in short, everything that in the thing itself impels the gift and the annulment of the gift." (Derrida, 1994, p. 24) He further observes that the interval between exchange of gifts that is between gifts and return gifts enables Mauss to overlook the fact that gifts can no longer remain gifts if these are exchanged. Even though Mauss highlights the issue of exchange he significantly fails to notice that exchange of gifts leads to the annulment of gift itself - that gift and exchange are contradictory. Derrida writes, "Mauss does not worry enough about this incompatibility between gift and exchange or about the fact that an exchanged gift is only a tit for tat, that is, an annulment of the gift." (Derrida, 1994, p. 37) The time gap between gift and return gift, which Mauss overlooks, is the cardinal quality of gift according to Derrida and that which distinguishes gift-exchange from other forms of exchange. "The gift gives, demands, and takes time." (Derrida, 1994, p. 41) Nevertheless, as there is exchange there is annulment of the gift.

For a gift to be a gift, for there to be a gift-event Derrida identifies certain conditions. There must be a doner, a donee and a gift object. Donor/donee may be collective. Further, there must not be any giving back --- "no reciprocity, return, exchange, countergift, or debt" (Derrida, 1994, p. 12) in any point of time for these lead to annulment of the gift. Not only goods but values and symbols and also intentions to give --- intentions conscious or unconscious --- lead to annulment of the gift. So, the donee should not only not give back but also should not recognise the gift as gift for such recognition entails the very thought of giving back. Thus, for Derrida, even a thought for reciprocating is powerful enough to annul a gift and, therefore, the onus is on the donee not to recognise the gift as gift and in doing so make the gift a gift. And obviously, the donor too should not only receive something in return but also should not perceive what she/he is giving as a gift. For once she/he perceives the gift as gift she/he expects return, either symbolically or otherwise. Even if there is no return from the donee Derrida argues that if the donor perceives the gift as gift she/he then tends to "pay himself with a symbolic recognition, to praise himself, to approve of himself, to gratify himself, to congratulate himself, to give back to himself symbolically the value of what he thinks he has given or what he is preparing to give" (Derrida, 1994, p. 14), that is, to seek glory in giving and thereby destroy the gift as gift and transform it to exchange. Further, Derrida proceeds to observe that even if one wants to give a gift sans any consideration then also the gift is not a gift as there is a want to give. In such a case also the gift gets annulled for one gives to satisfy a want to give. In light of Derrida's understanding of gift let us now briefly take up Titmus' The Gift Relationship: From Human Blood to Social Policy. In this book Titmus explores a specific kind of gift - the gift of blood. For him, gift of blood is a true gift as neither the donor, who gives altruistically under most circumstances, wishes for a similar return gift nor is the donee obliged to return as such gifting is often impersonal giving where the giver and recipient remain anonymous to each other (Titmus, 1970, p. 73). But, following Derrida, it can be argued that even the impersonal gifting of blood does not remain a gift if the donor gratifies herself/himself by giving her/his blood, is driven by a want to give or on the least considers the giving of blood as making a gift. Moreover, if the donee receives the blood and perceives it as gift then also the gift of blood is annulled as a gift.

What Derrida does is that he unravels the paradoxes of gift -- for a gift to become and exist as a gift it cannot be identified as a gift for such identification leads to its destruction. Derrida goes to the extent to observe that even if someone declines to accept a gift then also there is the annihilation of the gift if the refuser marks the gift as gift. So, in short, we can say that the very thought of a gift to be a gift annuls the gift and herein lies its 'tragedy'. Even reason, morality, duty, generosity which encourages one to bestow a gift makes the gift interested and thus annuls it as a gift. In Gift of Death Derrida writes "The moment the gift, however generous it be, is touched by the slightest hint of calculation, the moment it takes account of knowledge [connaissance] or recognition [reconnaissance], it allows itself to be caught in transacting..." (Derrida, 2008, p. 113) and this annuls the gift. 


\section{CONCLUSION}

In the final analysis, we cannot deny Mauss' understanding that gifts are bestowed under obligations and are expected to be exchanged. Once we accept this position we have to acknowledge Derrida's understanding of gift and thus acknowledge that a gift, in its truest sense, is an impossibility. Given this, let us accept gift-giving and reciprocating as a kind of exchange but that which is different from other forms of exchange. In case of gift exchange there is pretence that gifts are given and returned voluntarily - as if gifts are given neither under any obligation nor is any return expected - as if one is not contract bound to give and return gifts. Whereas, in other forms of exchange there is no such pretence. There is a contract, either written or unwritten, according to which exchange takes place. Further, values of objects exchanged are predetermined between parties involved in other forms of exchange. Whereas, in case of gift exchange values are not predetermined and one supposedly has the freedom to return a gift, in case she/he wants to reciprocate, having value not corresponding to the value of the gift received. Also, either the original gift or the return gift or both can be symbolic and thus not always measurable in terms of money or other scales of value measurement.

Derrida identifies that unlike other forms of exchange gift is not reciprocated by a return gift immediately. And here lies the difference between a gift exchange and other forms of exchange according to Derrida. The gift cannot be recompensed immediately when it is given. There has to be a pause, a time gap. But this time gap cannot be forgotten and it is "neither an instant nor an infinite time, but a time determined by a term, in other words, a rhythm, a cadence. The thing is not in time; it is or it has time, or rather it demands to have, to give, or to take time--- and time as rhythm, a rhythm that does not befall a homogeneous time but that structures it originarily." (Derrida, 1994, p. 41) Thus, in case of gift exchange the return is mostly not immediate and there is no real contract specifying both the time limit of giving the return gift and the punitive measures that may be taken in case no return is made. In other forms of exchange there may be few occasions where there is time gap between objects, etc. exchanged. But in such situations there are contracts, written or verbal, specifying the time within which the predetermined return should be made and also indicating penal measures that may be taken recourse to in case of no return within the specified time limit.

In modern societies, in case of most gifts, there is the absence of any legal binding and formal contract. For this, there is uncertainty of return gift and also uncertainty about the value of the return gift. As gifts are mostly given in occasions there is always the possibility of not getting a return gift if an occasion does not arise in future. Unlike other forms of exchange as gifts cannot always be measured in monetary terms the scope of concealing the money value of the gift and return gift is always very high. Neither is bargaining possible here nor is it an approved gesture. In case of no return or less return what can happen at the most is the honour of the donee may be at stake if her/his failure to return a gift is revealed. Again, the honour of the donor is put at stake when a gift is refused or returned. In other forms of exchange the nature of refusal or return is different and honour of neither party is at stake.

\section{REFERENCES}

[1] Derrida, J. (1994). Given Time: I. Counterfeit Money (P. Kamuf, Trans.), (Paperback Edition). Chicago: The University of Chicago Press. (Original work published 1991).

[2] Derrida, J. (2008). The Gift of Death ( $2^{\text {nd }}$ Ed.) and Literature in Secret (D. Wills, Trans.), Chicago: The University of Chicago Press. (Original work published 1999).

[3] Emerson, R.W. (1898). Essays (Second Series, Volume III, Emerson's Complete Works). London: George Routledge and Sons, Limited.

[4] Mauss, M. (2011). The Gift: Forms and Functions of Exchange in Archaic Societies (I. Cunnison, Trans.). Mansfield Centre, CT 06250 USA: Martino Publishing. (Original work published 1954).

[5] Titmus, R.M. (1970). The Gift Relationship: From Human Blood to Social Policy. London: George Allen \& Unwin Ltd. 